\title{
THE FIFTH LIBERAL ARTS INTERNATIONAL CONFERENCE: REINVENTING OURSELVES: INNOVATION AND THE LIBERAL ARTS, Doha, Qatar, 29-31 January 2017
}

\section{ПЯТАЯ МЕЖДУНАРОДНАЯ КОНФЕРЕНЦИЯ \\ ПО ГУМАНИТАРНЫМ НАУКАМ: «ПЕРЕОСМЫСЛЕНИЕ СВОЕГО „Я" И ИННОВАЦИИ В СФЕРЕ ГУМАНИТАРНЫХ НАУК”, Доха, Катар, 29-31 января 2017 г.}

Since 2013 the Liberal Arts Program at Texas A\&M University at Qatar has been hosting an annual international conference exploring interdisciplinary approaches to selected topics in arts, humanities and socials sciences. This year the conference theme was 'Reinventing ourselves: innovation and the Liberal Arts' and took place from 29-31 January 2017 in the Student Center Hamad Bin Khalifa, situated in Education City on the outskirts of Doha.

The 2017 Liberal Arts International Conference (LAIC2017) featured a number of keynote lectures, thematic sessions and panel discussions. The conference was officially opened by Professor César Malavé, Dean of Texas A\&M University at Qatar, who highlighted the importance of liberal arts research and education in the formation of future global professionals and leaders. In addition, Professor Zohreh R. Eslami, Chair of the Liberal Arts Program, further contextualised the issue, giving the floor to the members of the Organising Committee, this year chaired by Dr Phillip Gray.

The opening keynote lecture was given by Professor Roger Griffin (Oxford Brookes University, UK), entitled 'Retooling the humanities to prevent self-extinction: a liberal arts perspective', looking into the causes and consequences of the inadequacy and failure of the Western concept of Enlightenment Humanism. What is suggested as a possible solution is a form of transcultural humanism that will depart from a Euro-centric and anthropocentric models of the past, bringing together academic, religious and secular elites world-wide.

Professor Alastair Pennycook (University of Technology Sidney, Australia), who gave the second keynote lecture, entitled 'Disinvention and reinvention: rethinking language and ourselves', put forward a new model of communication. The model takes into account the requirements of post-modernity, impacting profoundly on our linguistic identity and, consequently, on the design and delivery of language education across levels and domains.

LAIC2017 featured several thematic sessions, clustering around topics in education, politics, religion, etc, but linguistic perspectives on innovation in liberal arts had quite a prominent presence in the conference programme. Some of these sessions saw the par- 
ticipation of distinguished members of the European Network for Intercultural Education Activities (ENIEDA), a transnational collaborative network committed to setting up and sustaining exploratory dialogue within, across and beyond disciplinary and geographical boundaries on topics pertaining to interculturality. One such thematic session was entitled 'Language and innovation', featuring presentations by Dr Łukasz Grabowski (Opole University, Poland; ENIEDA Network) and Dr Jagoda Granić (University of Split, Croatia; ENIEDA Network). Dr Grabowski, whose presentation was entitled 'New methods, old problems: innovation in descriptive translation studies research', showed how computational tools, electronic text corpora and quantitative research methods have recently changed and transformed the landscape of descriptive research in translation studies. Dr Granić, on the other hand, presenting the paper 'Reconstructing identities in a transnational world', elaborated on the theoretical underpinnings of the process of identity reconstruction in a globalised, transnational world, highlighting the social semiotic component of language and communication. The session ended with a presentation by Dr Sara Hillman and Emilio Ocampo Eibenschutz (Texas A\&M University at Qatar), who presented preliminary results of their ongoing research project on language and identity attitudes among Qatari Arabic-English bilingual speakers.

Two additional thematic sessions deserve to be singled out. More specifically, a session on Interdisciplinary approaches to innovation in religion studies, featuring a presentation by another prominent ENIEDA Network member. Namely, Dr Monika Kopytowska (University of Łódź, Poland; ENIEDA Network) presented her work in the area of cognitive approaches to Critical Discourse Analysis and Proximization Theory, championing a new model for understanding the interface between religion, media and social cognition. In her presentation entitled 'Media, technology and the sacred: a new perspective on (mediated) religious experience' Dr Kopytowska put forward new insights into the role that language plays in mediating the experience of religious practitioners. The role of liberal arts in issues in global crises was discussed during the final session of the conference, featuring the participation of Dr Noémie Hermeking (Eberhard Karls Universität Tübungen, Germany; ENIEDA Network), who highlighted the importance of well-developed intercultural skills and awareness for professionals and volunteers dealing with refugee and immigrant communities in Germany. Dr Hermeking's approach, elaborated in her presentation entitled 'Refugee crisis and diasporas - intercultural training for organisations working with the newly arrived in Germany', although essentially anthropological, is highly relevant to a variety of fields, most notably intercultural pragmatics and communication, crucially informing post-modern requirements of effective competency-based education.

Innovative approaches to intercultural communication were given a prominent role in a separate thematic panel entitled 'Where next for intercultural education? Towards a sustainable post-method model'. The panel was organised by Dr Svetlana Kurteš (Texas A\&M University at Qatar; ENIEDA Network) and saw the participation of Professor Tatiana Larina (Peoples' Friendship University of Russia; ENIEDA Network) as an invited speaker. Dr Kurteš and Professor Larina elaborated on the current state of affairs in linguistic and intercultural education, taking the post-method pedagogy as their anchor point. The concept of interculturality was deconstructed from the point 
of view of intercultural pragmatics and current theoretical and methodological approaches therein. The panellists argued that the adequate development of intercultural awareness requires cross-curricular presence and a joint effort across educational levels, sharing examples of best practice from their own pedagogical experience. An engaging and lively discussion ended the session, including contributions from Professors Griffin and Pennycook as well.

Participants (Picture 1) agree that LAIC2017 was not only another successfully organised academic conference, but also a great networking opportunity, providing a unique forum for an engaging and focused cross-disciplinary dialogue. A mediumsized event with respect to the number of participants, the conference persuasively demonstrated its pluralistic ethos, represented by the linguistic, cultural and geographical diversity of its participants. Apart from the delegates coming from several higher education institutions in Qatar and the United Stated of America, there were also representatives from a number of European countries (UK, France, Netherlands, Russia, Poland, Croatia, Slovakia, Macedonia, Latvia, Lithuania, Denmark) and further afield (e.g. Brazil, Algeria, Australia, Pakistan, India, Sri Lanka). This was also highlighted in the closing remarks by Professors Malavé and Eslami, who also expressed their hope in the continued future success of LAIC conferences.

Two noteworthy post-conference events were convened for and by the members of the ENIEDA Network, who welcomed this unique opportunity to explore possible collaborative avenues with the colleagues from the Liberal Arts Program at Texas A\&M University at Qatar.

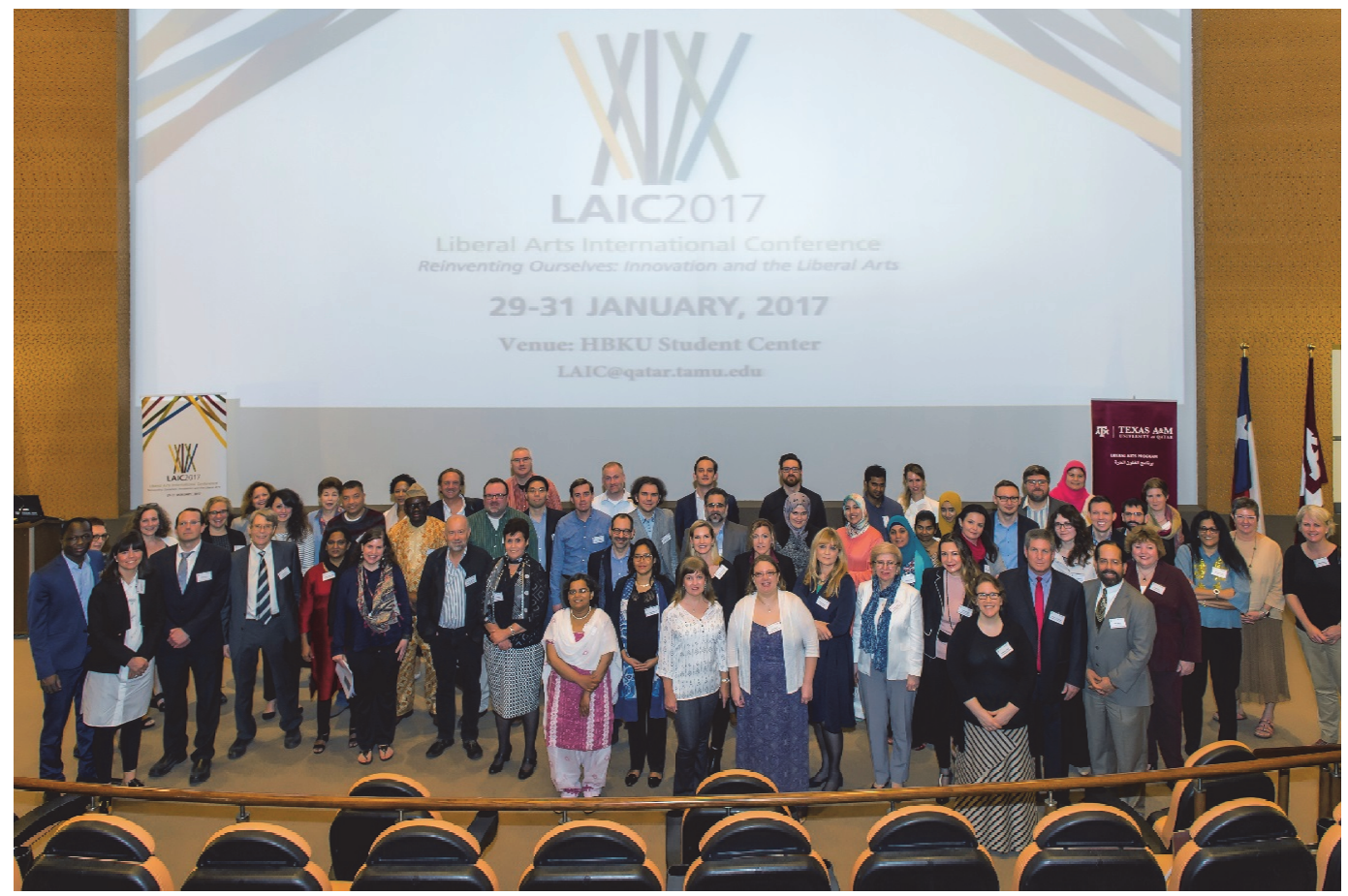

Picture 1: LAIC 2017 Conference participants 
On Wednesday, 1 February 2017 Dr Monika Kopytowska and Dr Eukasz Grabowski conducted a workshop for the students taking a course in Foundations of Education in a Multicultural Society, offered by Texas A\&M University both at its main campus in College Station, Texas and Qatar. The workshop, entitled 'Presenting for and interacting with intercultural audiences' gave the students an exciting opportunity to have some hands-on experience in aspects of intercultural communication, contextualising them within appropriate theoretical frameworks and then testing their validity through a number of effective and well-chosen role-play activities, illustrating instances of successful communicative events in intercultural settings.

The second post-LAIC event took place on Thursday, 2 February 2017, aiming primarily to inform the colleagues from the Liberal Arts Program about the activities, achievements and mission of the ENIEDA Network and identify possible common denominators in research and practice that could be further explored and developed collaboratively. Dr Svetlana Kurteš gave a short introductory presentation entitled 'ENIEDA Network: linguistic and intercultural education going beyond disciplinary and geographical borders', providing a platform for a lively and fruitful round table discussion that followed on (Picture 2).

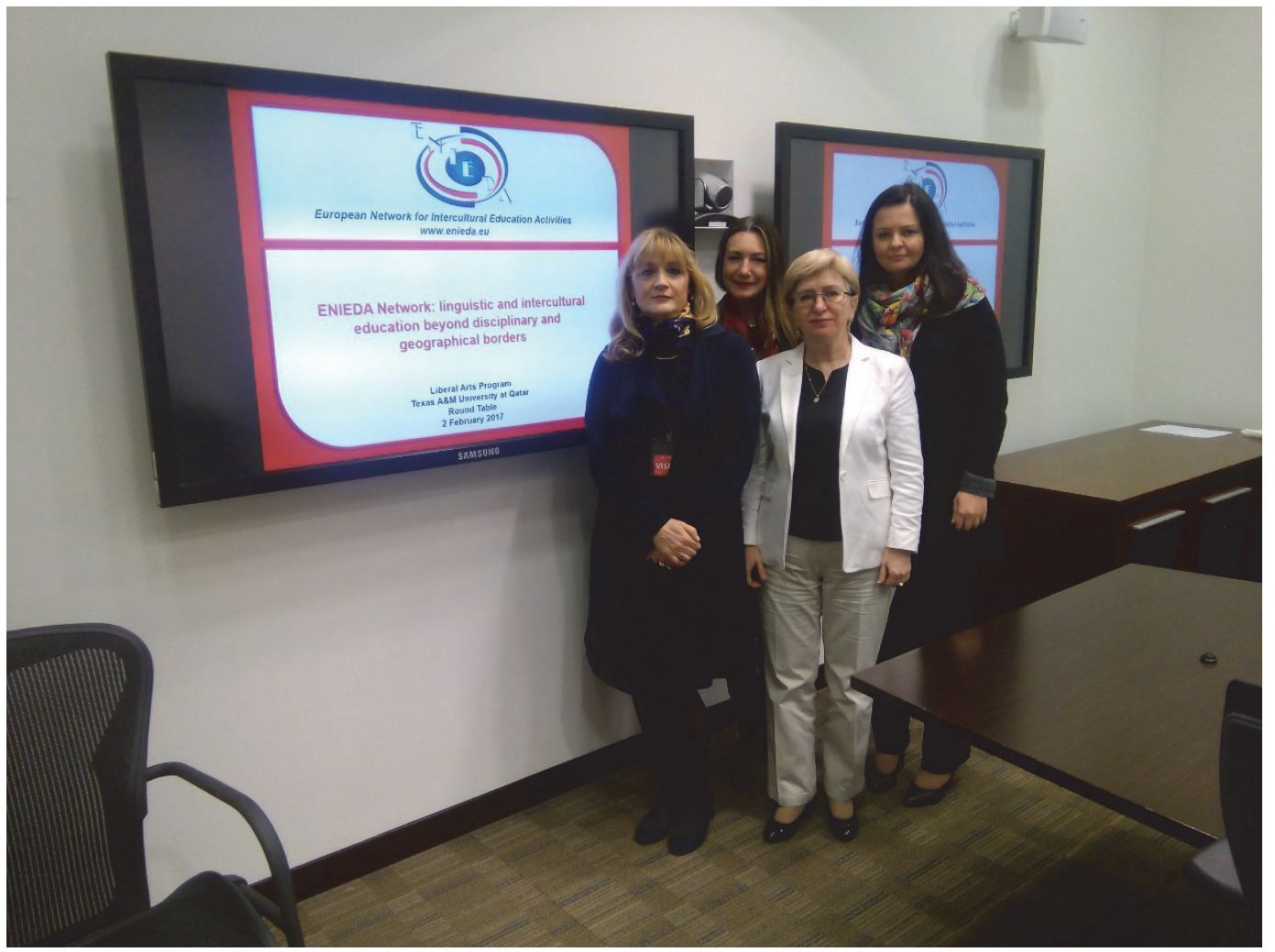

Picture 2: ENIEDA Round Table at TAMUQ 


\section{For Citation:}

Kurteš, S., Eslami, Z. (2017). The Fifth Liberal Arts International Conference: Reinventing Ourselves: Innovation and the Liberal Arts, Doha, Qatar, 29-31 January 2017. Russian Journal of Linguistics, 21 (2), 446-450.

\section{Bio note:}

Svetlana Kurtěs, Dr, Professor, currently affiliated with Texas A\&M University at Qatar, Vice President of the European Network for Intercultural Education Activities (ENIEDA), member of several professional and scholarly associations and editorial boards of academic journals, a Fellow of the Higher Education Academy, UK. Research Interests: interdisciplinary approaches to communication, culture and society and issues surrounding their practical applications and pedagogical implications. Contact information: e-mail: svetlana.kurtes@enieda.eu

Zohreh R. Eslami, Dr, Professor, Chair of Liberal Arts Program of Texas A\&M University at Qatar and Professor in the Department of Teaching, Learning and Culture of Texas A\&M University, USA, member of the International Advisory Board of the European Network for Intercultural Educational Activities (ENIEDA), member of the editorial board of Russian Journal of Linguisitics. Research Interests: Persian Pragmatics and Politeness, Intercultural and Instructional Pragmatics, L2 Content Literacy Development, Linguistic Development and Assessment of English Language Learners. Contact information: e-mail: zohreh.eslami@qatar.tamu.edu

\section{Для цитирования:}

Kurteš, S., Eslami, Z. The Fifth Liberal Arts International Conference: Reinventing Ourselves: Innovation and the Liberal Arts, Doha, Qatar, 29-31 January 2017 // Вестник Российского университета дружбы народов. Серия: Лингвистика. 2017. Т. 21. № 2. С. 446-450.

\section{Сведения об авторах:}

Светлана Куртеш, доктор, профессор, научный сотрудник Техасского университета A\&M в Катаре, вице-президент Европейской ассоциации по межкультурному образованию (ENIEDA), член различных международных организаций в сфере профессиональной деятельности, член ряда международных научных организаций и редколлегий научных журналов, член Академии высшего образования (Великобритания). Сфера научных интересов: междисциплинарные подходы к коммуникативистике, культура и общество, методика преподавания. Контактная информация: e-mail: svetlana.kurtes@enieda.eu

Зохрэ Еслами, доктор, профессор, заведующая кафедрой преподавания, изучения языков и культур Техасского университета А\&М в Катаре (Доха, Катар). Сфера научных интересов: межкультурная прагматика, член Европейской ассоциации по межкультурному образованию (ENIEDA), член редколлегии журнала Вестник Российского университета дружбы народов. Серия: Лингвистика. Сфера научных интересов: прагматика (персидский язык), теория вежливости, межкультурная прагматика, методика преподавания второго иностранного языка, формирование культурных компетенций в рамках изучения иностранного языка. Контактная информация: e-mail: zeslami@tamu.edu 